\title{
Seasonal variation in fish bycatch associated with an artisanal flounder fishery on Coquimbo Bay, Chile
}

Variación estacional de la fauna íctica asociada a la pesquería artesanal del lenguado en Coquimbo, Chile

\author{
Sebastián Hernández ${ }^{1,2}$, María Teresa González ${ }^{3}$, Juan Carlos Villarroel ${ }^{1,4}$ \\ and Enzo Acuña ${ }^{1}$
}

\author{
${ }^{1}$ Departamento de Biología Marina, Facultad de Ciencias del Mar, Universidad Católica del Norte, Casilla 117, Coquimbo, \\ Chile. sebastian.hernandez@vuw.ac.nz \\ ${ }^{2}$ School of Biological Sciences, Victoria University of Wellington, PO Box 600, Wellington 6140, New Zealand \\ ${ }^{3}$ Instituto de Investigaciones Oceanológicas, Universidad de Antofagasta, Casilla 117, Antofagasta, Chile \\ ${ }^{4}$ Dirección Zonal de Pesca XV, I y II regiones, Avda. Arturo Prat 920, Iquique, Chile
}

\begin{abstract}
Resumen.- Se reporta la composición estacional de la fauna acompañante de la pesquería artesanal del lenguado en la bahía Coquimbo, entre octubre 2006 y noviembre 2007. Las especies desembarcadas fueron identificadas y pesadas $(\mathrm{kg})$. Estos datos fueron utilizados para estimar la importancia relativa en peso y la frecuencia de ocurrencia de las especies respecto al total de la captura. Para evaluar la variación estacional de las especies desembarcadas, se realizaron análisis de clusters (basados en la frecuencia de ocurrencia, peso promedio, CPUE) y análisis de correspondencia (frecuencia de ocurrencia; CPUE). Treinta y dos especies fueron registradas como fauna acompañante, siendo las más frecuentes, los condrictios Callorhinchus callorhynchus, Squatina armata y Mustelus mento. Paralichthys spp., C. callorhynchus, M. mento, Myliobatis chilensis, S. armata y Thyrsites atun predominaron en primavera y verano; mientras especies como Sciaena deliciosa y Merluccius gayi predominaron en invierno y otoño, respectivamente
\end{abstract}

Palabras clave: Fauna acompañante, red de enmalle, condrictios

\begin{abstract}
Seasonal bycatch composition of the flounder gillnet fishery in the Coquimbo Bay, between October 2006 and November 2007 was analyzed. Landed species were identified and weighted $(\mathrm{kg})$. These data set was used to estimate the relative importance of weight and frequency of occurrence of each species in relation to the total catch. To evaluate the seasonal variation of landed species, we performed cluster analyses (based on frequency of occurrence, mean weight, CPUE), and correspondence analysis (frequency of occurrence; CPUE). Thirty-two species were recorded as bycatch, being the most frequent species, the Chondrichthyan, Callorhinchus callorhynchus, Squatina armata and Mustelus mento. Paralichthys spp., C. callorhynchus, M. mento, Myliobatis chilensis, S. armata and Thyrsites atun, were strongly associated with spring and summer seasons; while Sciaena deliciosa and Merluccius gayi were associated with winter and autumn.
\end{abstract}

Key words: Bycatch, gillnet artisanal fishery, chondrichthyans

\section{INTRODUCTION}

Concerns over the impact and fishing on continental shelf resources have had emphasis on the concept of biodiversity (Stobutzki et al. 2003, Acuña et al. 2005, Amezcua et al. 2009). Most fisheries produce an evident impact, which is defined as the capture of non-target species, known as bycatch. This impact is divided in direct (e.g., changes in the abundance, size and age structure), and indirect effects (e.g., trophic interaction and predator removal) (Stevens et al. 2000). Bycatch includes noncommercial species, as well as species that are retained and sold. However, its quantification and composition are still unknown in many Chilean fisheries, particularly the small scale artisanal ones (Acuña et al. 2005).
Currently, at the Coquimbo wharf $\left(29^{\circ} 57 \mathrm{~S}, 71^{\circ} 20 \mathrm{~W}\right)$ four main artisanal fisheries are operating for: the Chilean hake (Merluccius gayi), the red cusk eel (Genypterus chilensis), the black cusk eel (Genypterus maculatus), and two flounders (Paralichthys spp.) (Abarca et al. 1997, Acuña et al. 2007). The flounder artisanal fishery captures principally two sympatric species of the genus Paralichthys (P. microps and P. adspersus), which show a marginal landing record in comparison with the other target species in Coquimbo (less than 10\%, SERNAPESCA 2007). The artisanal fishing fleet is composed of boats between 6 to $12 \mathrm{~m}$ in length, operating with outboard engines. The main fishing gear consists of bottom gillnets, made up of 
varying numbers of nets, each of which measures $c a .4 \mathrm{~m}$ in height and $100 \mathrm{~m}$ in length, with a mesh size that varies between 150-180 mm (Acuña et al. 2007). The joined-gillnet can be composed by several nets and has a final extension between 600 to $900 \mathrm{~m}$ of length. They are usually set at between 5 and $30 \mathrm{~m}$ depth, about three times during each fishing trip. The capture is landed at the Coquimbo wharf where unprocessed fishes are auctioned and sold to local traders mainly for fresh human consumption (Acuña et al. 2007).

Including the target species, at least 21 fish species have been reported in the artisanal commercial flounder fishery from Coquimbo (Acuña et al. 2007) as well as in scientific surveys (Acuña et al. 1989). Bony fish showed the highest percentage by weight (73\%) being Paralichthys spp. and Pacific menhaden Ethmidium maculatum the most important species by weight and frequency of occurrence (Acuña et al. 2007). Taking into account only Chondrichthyan species, the elephant fish Callorhinchus callorhynchus and the smooth hound Mustelus mento were the most important species by weight and frequency of occurrence, respectively (Acuña et al. 2007).

According to the National Fisheries Service (SERNAPESCA 2007) database, fishermen record only target species (Paralichthys spp.). However, they are not identified to species-specific level. Bycatch and/or discarded species have never been recorded in the official statistics. Consequently, it is difficult to estimate the temporal effect of bycatch removed by this fishery. This paper analyzed the bycatch composition of the flounder fishery in the Coquimbo Bay, as well as its seasonal variations. These findings can be useful to evaluate the effects of this artisanal fishery on ichthyofauna composition, especially on chondrichthyan species, of Coquimbo Bay.

\section{MATERIAL AND METHODS}

\section{Area AND PERIOd of STUdy}

Landing data was recorded from the artisanal flounder fishery at the Coquimbo wharf. The flounder fishery activity was recorded monthly between October 2006 and November 2007, which comprised 480 fishing trips. The flounder fleet effort comprised 21 boats, which operate during the whole year in the same fishing zone (Coquimbo Bay).

\section{SAMPLING}

Landed species were identified and weighted $(\mathrm{kg})$ from each boat trip. All the species captured are retained for the fisherman because they are commercially valuable. Captured specimens of each chondrichthyan species were numbered, weighted, measured (total length, TL for sharks and chimeras; and disc width, DW for rays), and sexed. The rest of the species, even Paralychthys spp. were unmeasured because the flesh could be wasted by manipulation and consequently decrease their prices. For this reason, the fishermen just allow us to get data from

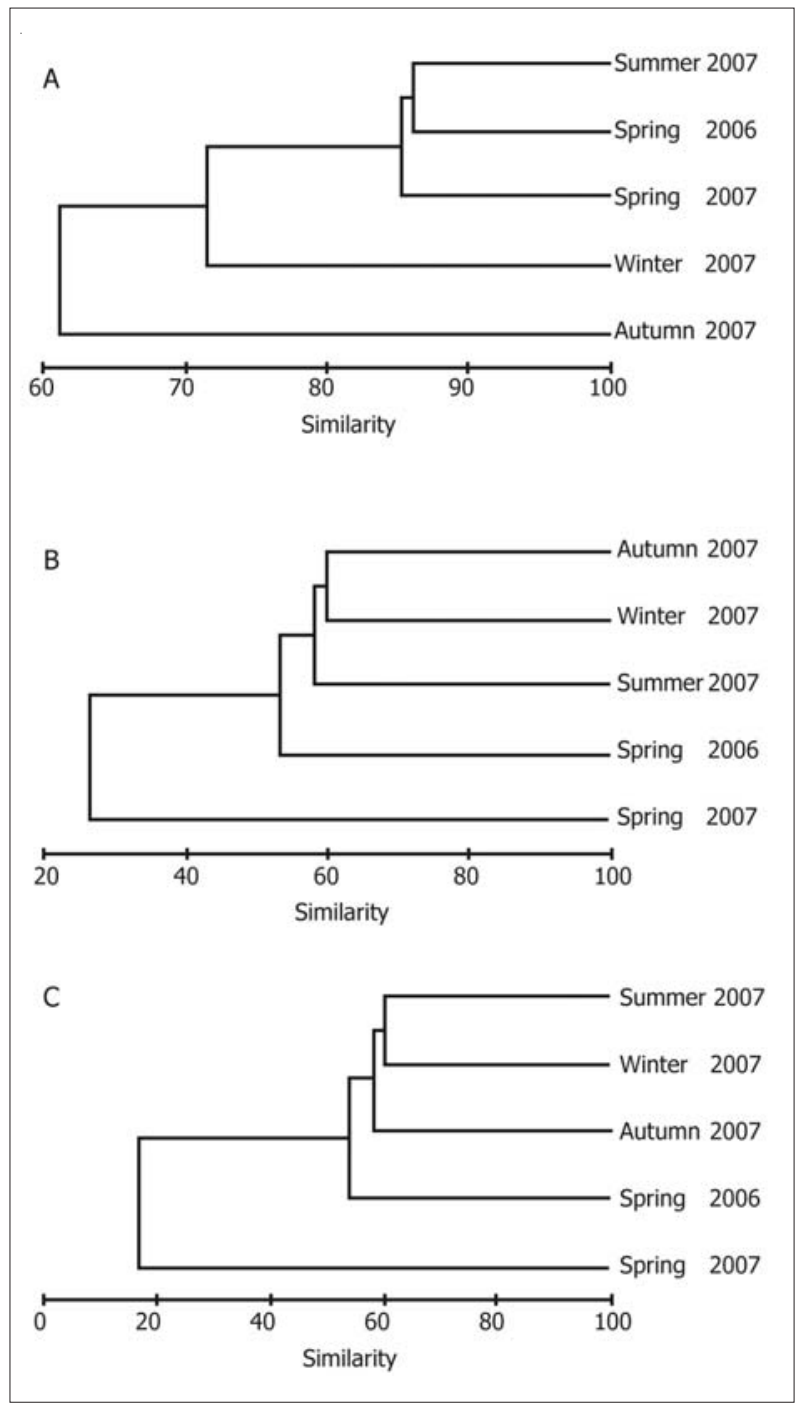

Figure 1. Seasonal clusters of landed species based on: A. frequency of occurrence; $B$ and $C$ species mean weight during study period / Agrupación estacional de las especies desembarcadas basada en: A. frecuencia de ocurrencia; $B$ y $C$ peso promedio de las especies durante el periodo de estudio 
chondrichthyan species. For each landing, we recorded total weight of captures, time of gillnets remain in the bottom, depth, locations, etc. (Acuña et al. 2007).

\section{Data ANalyses}

In order to assess the seasonal variations of bycatch, monthly captures were pooled and assigned as season according to annual calendar. Data from September to November were assigned to austral spring; DecemberMarch to summer; April-June to autumn and June-August to winter.

On a seasonal basis, we estimated the relative frequency of occurrence (number of trips when each species occurred divided per total number of trips into each season) and relative importance of weight (weight of each species divided by the total weight of all species captured into each season) of each species in relation to the total catch of the flounder fishery were estimated. Additionally, capture per unit of effort (CPUE) was calculated for each species by using as unit of effort the number of hours that nets were set per trip $(\Sigma f)$. We used two criteria to estimate seasonal CPUE for each species. First, captures were added and divided per the total number of trips into each season (CPUE1). Second criteria, mean captures by season were divided by total number of trips into each season (CPUE 2).

$$
\begin{aligned}
& \text { CPUE (1) }=\Sigma \text { captures } /(\Sigma \mathrm{f}) \\
& \text { CPUE }(2)=\text { Mean captures } /(\Sigma \mathrm{f})
\end{aligned}
$$

Patterns in the composition of landed species were explored with cluster analyses, based on relative frequency of occurrence of each species, relative weight, and CPUE (as defined above), respectively. Cluster analyses were performed using average group algorithm for the BrayCurtis similarity index (software Primer 5.0). These analyses were performed considering only those species with occurrences $>1 \%$ during each season. Additionally, correspondence analysis (using data of relative frequency of occurrence of species per each season) was used to assess the association between landed species and season (Quinn \& Keough 2002). This analysis was performed using the software STATISTICA 6.0 (Statsoft 2004).

To evaluate seasonal changes in size (and weight) between sex distributions of Callorhinchus callorhynchus a two-way analysis of variance was used (previous check of normality and variance homogeneity of data). If significant differences were detected a Tukey test was tested as post-hoc test. Since the data among seasons and sex is unbalance (due to logistical or randomness sampling) an effect size test was performed.

\section{Results}

The target species, Paralichthys spp., were recorded in $75 \%$ of fishing trips during the study period. The relative frequency of occurrence of target species was higher during austral spring (years 2006 and 2007) and summer (81-92\%), and lower during winter (67\%) and autumn (41\%). Thirty-two species were recorded as bycatch, being the most frequent species, the chondrichthyan, Callorhinchus callorhynchus, Squatina armata and Mustelus mento (Table 1).

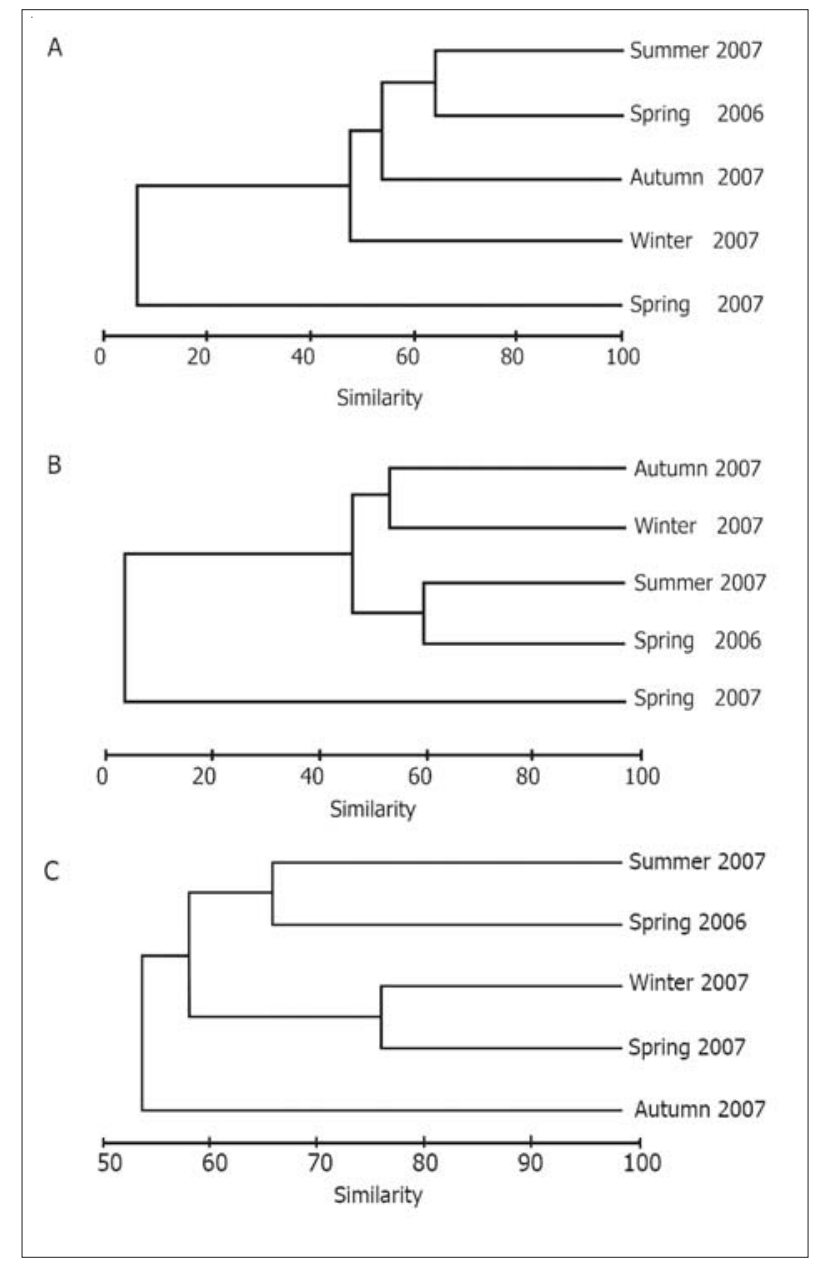

Figure 2. Seasonal clusters of landed species based on: A. CPUE criteria 1; B. CPUE criteria 2, during study period / Agrupación estacional de las especies desembarcadas basada en: A. CPUE criterio 1; B. CPUE criterio 2, durante el periodo de estudio 
Table 1. Seasonal occurrence of species landed by flounder artisanal fishery during study period / Ocurrencia estacional de las especies desembarcadas por la pesquería artesanal de lenguado durante el periodo de estudio

\begin{tabular}{|c|c|c|c|c|c|c|}
\hline Species & Spring 06 & Winter 07 & Autumn 07 & Spring 07 & Summer 07 & Total \\
\hline Paralichthys spp. & 53 & 53 & 53 & 53 & 53 & 53 \\
\hline Callorhinchus callorhynchus & 33 & 33 & 33 & 33 & 33 & 33 \\
\hline Squatina armata & 16 & 16 & 16 & 16 & 16 & 16 \\
\hline Mustelus mento & 18 & 18 & 18 & 18 & 18 & 18 \\
\hline Isacia conceptionis & 1 & 1 & 1 & 1 & 1 & 1 \\
\hline Trachurus murphyi & 2 & 2 & 2 & 2 & 2 & 2 \\
\hline Sciaena deliciosa & 3 & 3 & 3 & 3 & 3 & 3 \\
\hline Ethmidium maculatum & 4 & 4 & 4 & 4 & 4 & 4 \\
\hline Thyrsites atun & 7 & 7 & 7 & 7 & 7 & 7 \\
\hline Merluccius gayi & 4 & 4 & 4 & 4 & 4 & 4 \\
\hline Prolatilus jugularis & 1 & 1 & 1 & 1 & 1 & 1 \\
\hline Myliobatis chilensis & 5 & 5 & 5 & 5 & 5 & 5 \\
\hline Cilus gilberti & 3 & 3 & 3 & 3 & 3 & 3 \\
\hline \multicolumn{7}{|l|}{ Myliobatis sp. } \\
\hline Genypterus chilensis & 1 & 1 & 1 & 1 & 1 & 1 \\
\hline Myliobatis peruvianus & 2 & 2 & 2 & 2 & 2 & 2 \\
\hline Seriolella violacea & 4 & 4 & 4 & 4 & 4 & 4 \\
\hline \multicolumn{7}{|l|}{ Paralabrax humeralis } \\
\hline Mugil cephalus & 1 & 1 & 1 & 1 & 1 & 1 \\
\hline \multicolumn{7}{|l|}{ Psammobatis scobina } \\
\hline \multicolumn{7}{|l|}{ Menticirrhus ophicephalus } \\
\hline \multicolumn{7}{|l|}{ Genypterus maculatus } \\
\hline Sardinops sagax & 1 & 1 & 1 & 1 & 1 & 1 \\
\hline \multicolumn{7}{|l|}{ Cheilodactylus variegatus } \\
\hline Seriola lalandi & 1 & 1 & 1 & 1 & 1 & 1 \\
\hline \multicolumn{7}{|l|}{ Alopias vulpinus } \\
\hline \multicolumn{7}{|l|}{ Aplodactylus punctatus } \\
\hline \multicolumn{7}{|l|}{ Squalus acanthias } \\
\hline \multicolumn{7}{|l|}{ Dipturus chilensis } \\
\hline \multicolumn{7}{|l|}{ Pinguipes chilensis } \\
\hline \multicolumn{7}{|l|}{ Discopyge tschudii } \\
\hline \multicolumn{7}{|l|}{ Stromateus stellatus } \\
\hline \multicolumn{7}{|l|}{ Aphos porosus } \\
\hline Total & 73 & 73 & 73 & 73 & 73 & 73 \\
\hline
\end{tabular}

Cluster analyses based on relative frequency of occurrences of species (Table $1, \mathrm{n}=22$ ) showed $88 \%$ similarity between spring and summer. Winter and autumn appeared as separated groups with $72 \%$ and $62 \%$ similarity, respectively (Fig. 1A). The bycatch composition in terms of relative weight of species also varied during seasons, but this analysis showed a different seasonal pattern. The seasons of autumn and winter were grouped with $60 \%$ of similarity; this group was associated with summer $(58 \%$ similarity) and then to spring 2006 with a 53\% similarity. Spring 2007 appeared as a separated group, showing only a 17\% similarity with other seasons (Fig. 1B). However, this pattern could be influenced by the high weight catches of Thyrsites atun during spring 2007 (Table 2). Thus, a second analysis was done, excluding this species, which did not show significant changes respect to the first cluster structure (Fig. 1C). 
Table 2. Seasonal mean biomass (mean weight, $\mathbf{k g}$ ) of species landed by flounder artisanal fishery during study period / Biomasa estacional (peso promedio, $\mathrm{kg}$ ) de las especies desembarcadas por la pesquería artesanal de lenguado durante el periodo de estudio

\begin{tabular}{|c|c|c|c|c|c|c|}
\hline Species & Spring 06 & Winter 07 & Autumn 07 & Spring 07 & Summer 07 & Total \\
\hline Paralichthys spp. & 7.46 & 6.25 & 5.35 & 10.51 & 10.32 & 8.39 \\
\hline Callorhinchus callorhynchus & 8.67 & 33.11 & 26.72 & 17.74 & 17.20 & 20.90 \\
\hline Squatina armata & 11.82 & 10.66 & 10.72 & 7.42 & 8.98 & 9.74 \\
\hline Mustelus mento & 8.80 & 6.25 & 5.20 & 31.22 & 8.68 & 11.38 \\
\hline Isacia conceptionis & 2.00 & 8.67 & 4.69 & 1.41 & 1.40 & 4.06 \\
\hline Trachurus murphyi & 3.00 & 3.80 & 7.31 & 28.38 & 1.52 & 9.96 \\
\hline Sciaena deliciosa & 3.23 & 1.01 & 6.94 & 2.41 & 23.39 & 9.31 \\
\hline Ethmidium maculatum & 6.63 & 1.26 & 51.50 & 14.30 & 19.72 & 15.81 \\
\hline Thyrsites atun & 2.60 & 1366.49 & 4.52 & 6.15 & 0.84 & 231.17 \\
\hline Merluccius gayi & 6.55 & 6.00 & 1.06 & 1.04 & 3.09 & 2.70 \\
\hline Prolatilus jugularis & 0.30 & 0.60 & 2.85 & 0.25 & 0.77 & 1.86 \\
\hline Myliobatis chilensis & 69.20 & 93.15 & 57.22 & 99.50 & 23.50 & 83.73 \\
\hline Cilus gilberti & 6.00 & 3.33 & 18.00 & 4.73 & & 8.53 \\
\hline Myliobatis sp. & & 43.75 & 18.33 & 64.17 & 23.33 & 42.81 \\
\hline Genypterus chilensis & 6.50 & 8.00 & 6.17 & 6.00 & 11.67 & 7.37 \\
\hline Myliobatis peruvianus & 37.50 & 47.86 & 10.89 & 21.81 & & 30.40 \\
\hline Seriolella violacea & 2.88 & & 3.82 & & 2.00 & 3.42 \\
\hline Paralabrax humeralis & & 1.50 & & 5.67 & 1.25 & 3.21 \\
\hline Mugil cephalus & 1.00 & 0.85 & 2.06 & 20.00 & & 4.47 \\
\hline Psammobatis scobina & & 0.39 & 1.07 & 3.07 & & 1.29 \\
\hline Menticirrhus ophicephalus & & 1.13 & 0.70 & & 0.20 & 0.86 \\
\hline Genypterus maculatus & & & & 29.50 & 18.25 & 23.88 \\
\hline Sardinops sagax & 1.50 & 30.00 & 0.50 & & & 10.67 \\
\hline Cheilodactylus variegatus & & & 0.80 & 0.30 & 0.70 & 0.60 \\
\hline Seriola lalandi & 6.50 & & & 8.00 & & 7.50 \\
\hline Alopias vulpinus & & & & 8.94 & 9.40 & 9.17 \\
\hline Aplodactylus punctatus & & & 1.50 & & 0.70 & 1.10 \\
\hline Squalus acanthias & & 2.77 & & & & 2.77 \\
\hline Dipturus chilensis & & & & 2.86 & & 2.86 \\
\hline Pinguipes chilensis & & & & 1.00 & & 1.00 \\
\hline Discopyge tschudii & & & & & 0.70 & 0.70 \\
\hline Stromateus stellatus & & & 0.60 & & & 0.60 \\
\hline Aphos porosus & & & 0.50 & & & 0.50 \\
\hline
\end{tabular}

Cluster based on CPUE, using criteria 1 and criteria 2 (Fig. 2) were roughly concordant between them, both showed spring 2007 as a separated branch with only $10 \%$ of similarity respect to other seasons, and spring 2006 and summer 2007 were grouped with 62\% of similarity (Fig 2A and $2 \mathrm{~B}$, respectively). Although with some differences, these clusters were more similar to those based on relative mean weight of species (Fig. 1B and 1C). CPUE is used as a measure of species abundances in fishing zone; therefore the high weight captures of Thyrsites atun during spring 2007 influenced these results. Thus, a new analyses, using CPUE criteria 1, was done and excluding T. atun, obtaining a different seasonal pattern, and a higher species composition similarity among seasons (Fig. 2C).

Correspondence analysis based on frequency of occurrence of species showed significant differences among seasons (Total Inertia $=0.1705 ; \chi^{2}=187.43 ; \mathrm{df}=$ 56; $P<0.001)$. Flounder species, and bycatch species: 


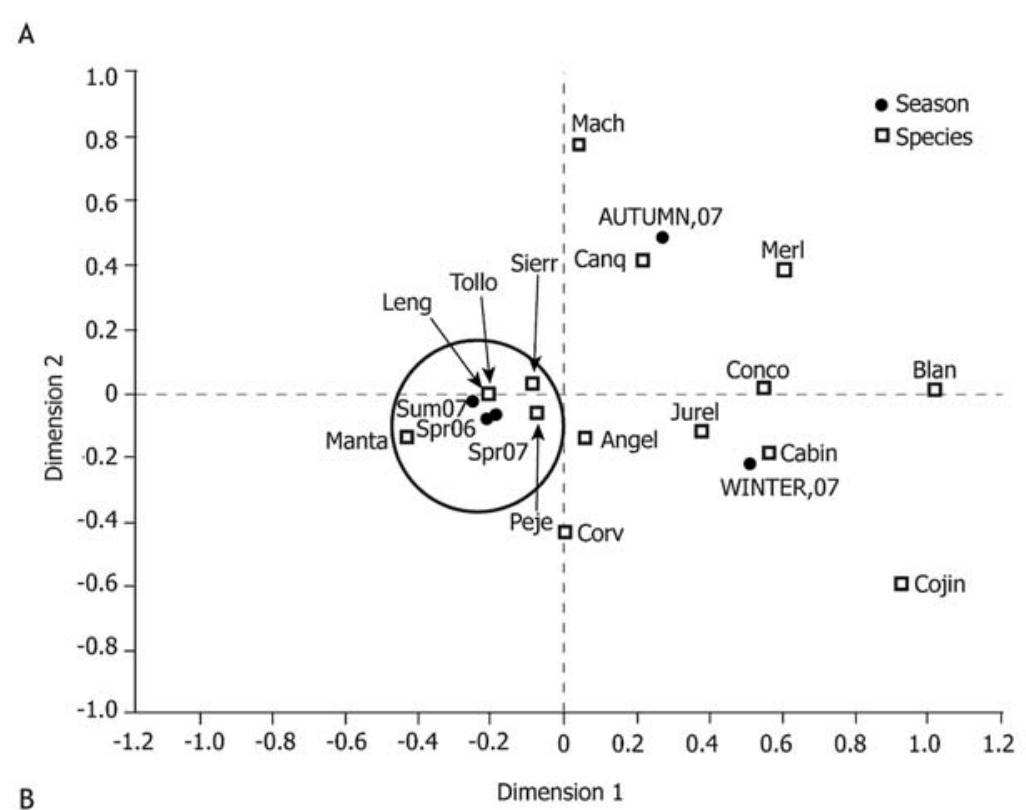

B

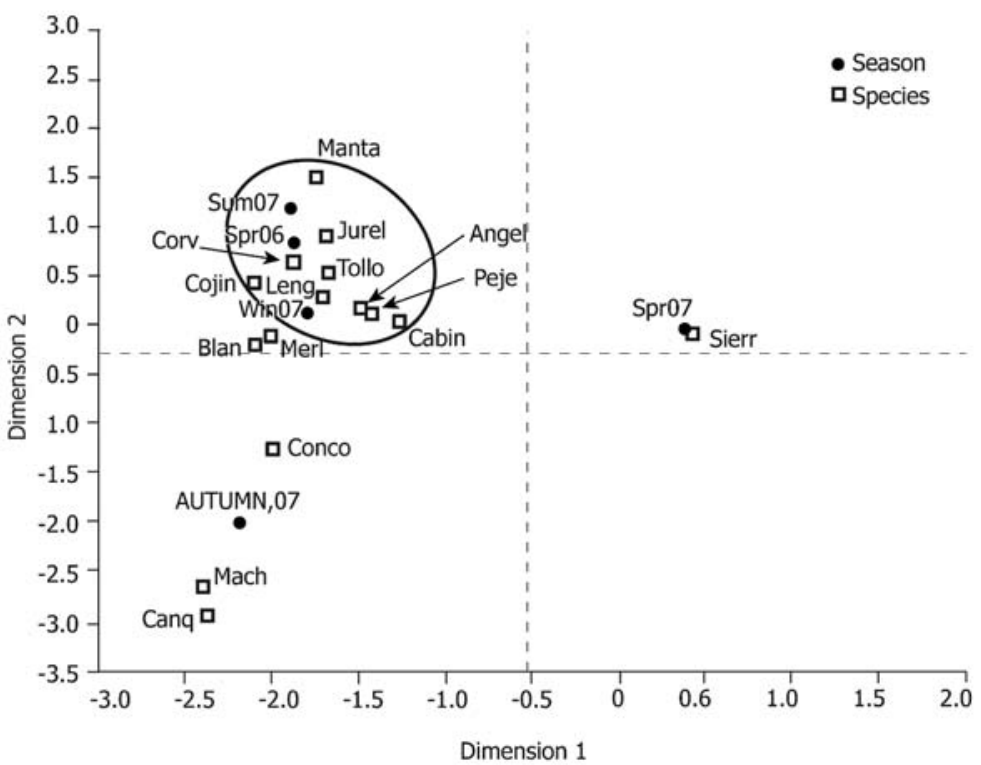

Leng: Paralichthys spp.; Peje: Callorhinchus callorhynchus; Tollo: Mustelus mento; Sierr: Thyrsites atun; Manta: Myliobatis chilensis; Jurel: Trachurus murphyi; Cabin: Isacia conceptionis; Canq: Sciaena deliciosa; Merl: Merluccius gayi; Corv: Cilus gilberti; Angel: Squatina armata; Conco: Genypterus chilensis; Mach: Ethmidium maculatum; Blan: Prolatilus jugularis; Cojin: Seriolella violacea.

Figure 3. Correspondence analysis between landed species and season based on: A. species frequency of occurrence; B. CPUE criteria 1 / Análisis de correspondencia entre las especies desembarcadas y la estación basada en: A. frecuencia de ocurrencia de las especies; B. CPUE criteria 1

C. callorhynchus, M. mento, T. atun and Myliobatis chilensis were strongly associated with spring and summer seasons; while Trachurus murphyi and Isacia conceptionis were associated with winter and Sciaena deliciosa and Merluccius gayi with autumn (Fig. 3A). Correspondence analysis based on CPUE (criteria 1) and excluding effect of T. atun, showed that Paralichthys spp., $M$. mento and $M$. chilensis were most associated with spring 2006 and summer 2007; C. callorhynchus S. armata and T. murphyi were associated with spring 2007. Ethmidium maculatum and Sciaena deliciosa were associated to autumn (Total Inertia $=1.2055 \chi^{2}=140.64$; df $=56$; $P<<0.0001$, Fig. 3B). Correspondence analysis based on CPUE (criteria 2) showed non significant differences in 


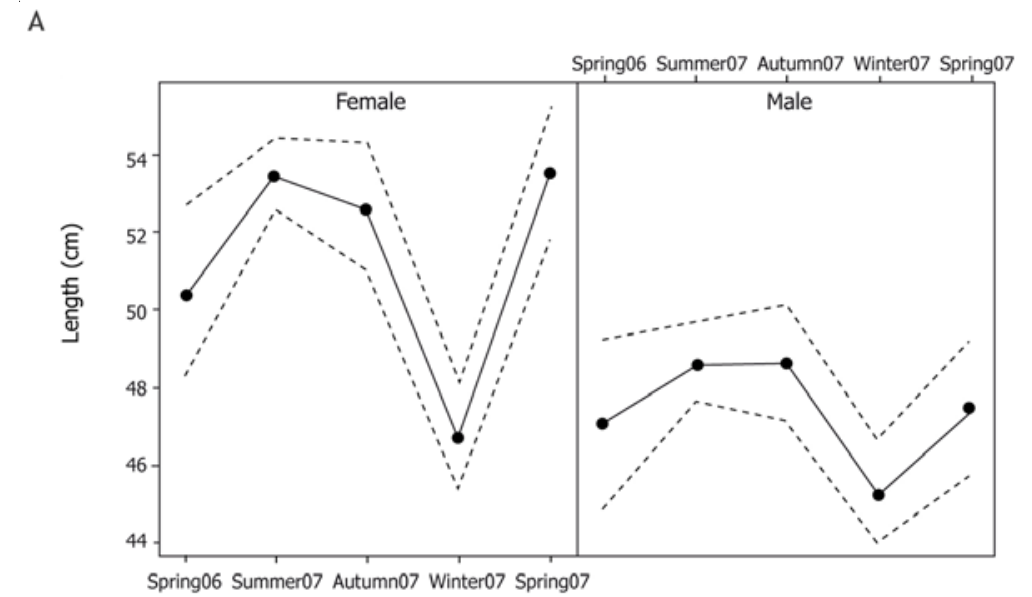

B

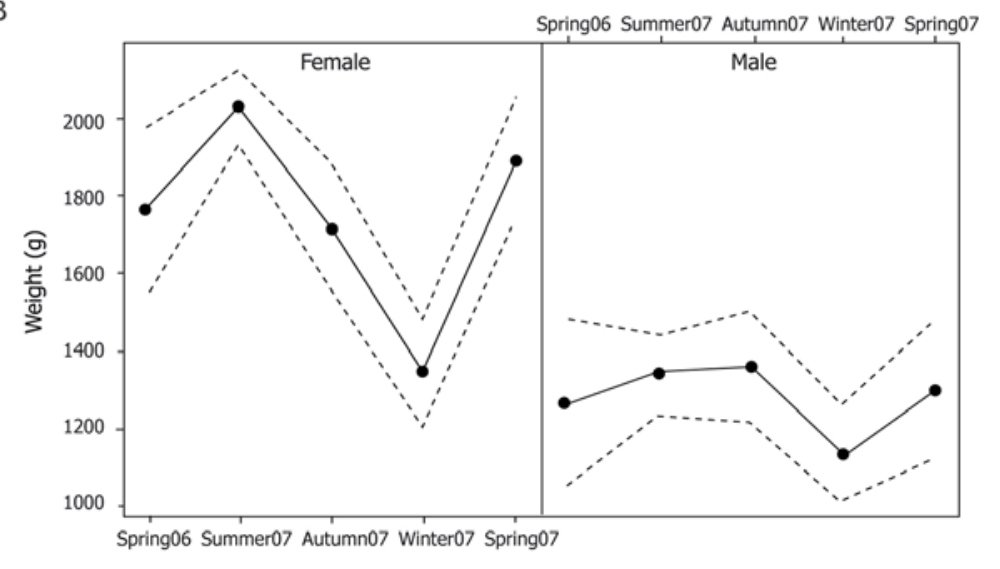

Figure 4. Effect sizes on: A) seasonal mean length $(\mathrm{cm})$ and B) mean weight (g) of Callorhinchus callorhynchus by sex recorded in Coquimbo Bay between spring 2006 and spring 2007. Dash lines represent $95 \%$ confidence intervals / Tamaño del efecto en: A) longitud media (cm) estacional y B) peso promedio (g) de Callorhinchus callorhynchus por sexo, registrada en la bahía Coquimbo entre primavera 2006 y primavera 2007. Las líneas punteadas representan $95 \%$ de intervalos de confianza the total composition of species, despite of some few species were most abundant in some season (Total Inertia $=0.49240 \chi^{2}=12.053 ; \mathrm{df}=52 ; P=0.99$ ).

There were significant differences in the size distribution between sex $\left(\mathrm{F}_{1,1343}=98.7231, P<0.001\right)$, among seasons $\left(\mathrm{F}_{4,149479}=14.8439, P<0.001\right)$ and the interaction between them $\left(\mathrm{F}_{4,1113}=3.3045, P<0.05\right)$. The post-hoc Tukey test revealed that females were bigger than males, and that females were bigger in spring 2007 and summer 2007 (Fig. 4).

\section{Discussion}

This study has demonstrated that flounder fishery of Coquimbo bay, Chile affect mainly chondrichthyan species such as Callorhinchus callorhynchus, Mustelus mento, Myliobatis spp. and Squatina armata. These species were strongly associated to spring and summer seasons during the sampling. In addition, the effect size model showed a tendency of sex biased of $C$. callorhynchus seasonally. It apparently may suggest the presence of breeding ground of $C$. callorhynchus, which were clearly bigger (in size and weight) from early spring to summer in Coquimbo Bay. However, more reproductive biology studies of $C$. callorhynchus and the rest of chondrichthyan species are needed, in order to support the evidence of our finding.

All these characteristics are taking account in term of management and conservation.

Because they have K-strategy life histories (e.g., low growth rates, late maturation, and extensive gestation periods), they are commonly vulnerable to over-fishing (Stevens et al. 2000). In this context, the implementation of continued time series of bycatch and encouraging the efforts to study these species in Chilean fisheries, e.g., assessing the effect of fishing on species abundances and diversity, is a priority. For this purpose, we also recommend to improve the official landing reports and the biological status of Chilean chondrichthyan species (e.g., reproduction, feeding habits, age and growth estimation, etc.). 


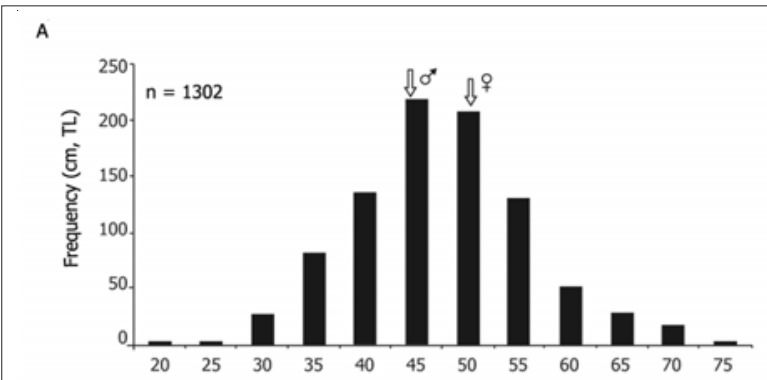

B

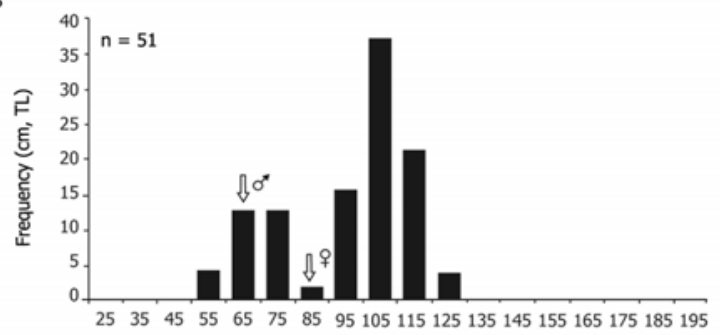

C
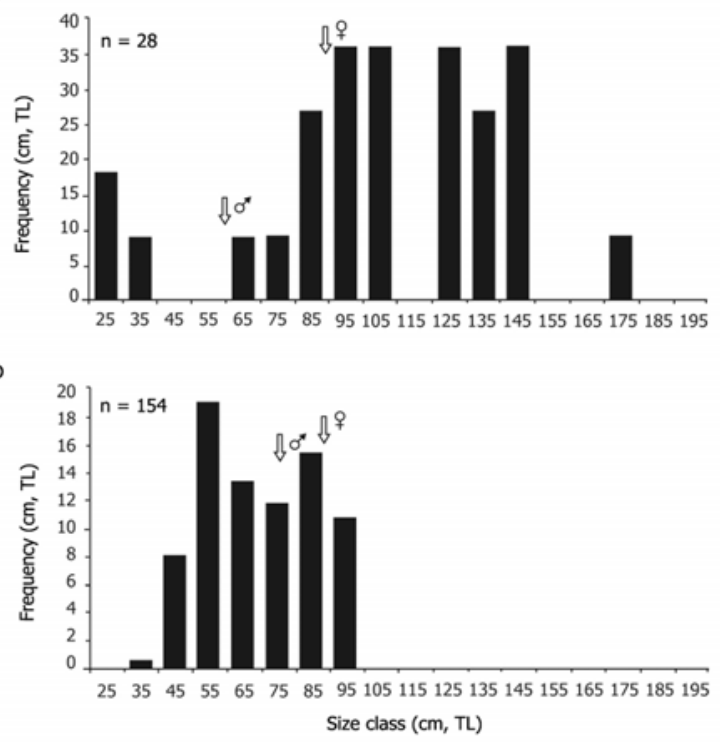

Figure 5. Size frequency distribution of (A) Callorhinchus callorhynchus, (B) Mustelus mento, (C) Myliobatis spp., (D) Squatina armata. The arrows show the minimum size at sexual maturity of females and males / Distribución de frecuencia de tallas de (A) Callorhinchus callorhynchus, (B) Mustelus mento, (C) Myliobatis spp., (D) Squatina armata. Las fechas indican la longitud minima de madurez sexual para hembras y machos

Our results show clear seasonal patterns of frequency of occurrence for target and bycatch species, which were more frequently landed during spring and summer. At least six species are highly associated: Paralichthys spp., $C$. callorhynchus, M. mento, M. chilensis, S. armata and T. atun. On the other hand, there are some species such as $S$. deliciosa and M. gayi which were associated only during winter and autumn respectively. Most of the species listed in this study have been reported in the Coquimbo Bay (Abarca et al. 1997, Acuña et al. 1989, 2005, 2007, Aedo et al. 2009) and in other three bays closely distributed in this geographic area: Tongoy, Guanaqueros and La Herradura (Acuña et al. 2007, SERNAPESCA 2007). This marine system composed by four bays is very productive, and is characterised by seasonally stronger upwelling between Punta Lengua de Vaca $\left(29^{\circ} \mathrm{S}\right)$ and Punta Pájaros $\left(30^{\circ} \mathrm{S}\right)$ (Acuña et al. 1989, Thiel et al. 2007). It also provides feeding, spawning and nursery grounds for $P$. adspersus and P. microps (Acuña \& Cid 1995). Also larvae and juveniles of Engraulis ringens, Leptonotus blainvillianus, Isacia conceptionis, and Normanichthys crokeri occur in high number in Coquimbo Bay (Acuña et al. 1989).

Biological data is available for some of the species captured as bycatch of the flounder fishery from Coquimbo. Aedo et al. (2009) found that sexual maturity in both males and females of C. callorhynchus occurs between $44.0 \mathrm{~cm}$ and $50.2 \mathrm{~cm}$ standard length (SL), respectively. Lamilla et al. (2005) also reported that sexual maturity ranged between $65 \mathrm{~cm}$ TL in males and $86 \mathrm{~cm}$ TL in females of the smooth hound $M$. mento, and between 75 and $86 \mathrm{~cm}$ TL both for $S$. armata males and females, respectively. Taking these parameters into account, our results suggest that more than $54 \%$ and $67 \%$ of the $C$. callorhynchus and $S$. armata sampled in this study were composed by juvenile specimens (Fig. 5A, D), while, $M$. mento showed mainly adults and less than $20 \%$ specimens landed were juveniles.

For species like Myliobatis spp., there is no information about sexual maturity size. However, based upon the sexual maturity of M. californicus (Martin \& Cailliet 1988) we can suggest that less than $20 \%$ of juveniles are landed, with most of the individuals being adults. Additionally, fisherman frequently release the small captured Myliobatis spp. (less than $45 \mathrm{~cm} \mathrm{DW}$ ), because they do not have a commercial value. However, some of them are still landed (Fig. 6C).

In conclusion, chondrichthyan species such as Callorhinchus callorhynchus, Mustelus mento, Myliobatis spp. and Squatina armata are commonly taken as bycatch in the flounder fishery in the Coquimbo Bay, Chile. However, little information about their biology is available at this time, and therefore it is important to increase the studies and knowledge, to improve our understanding about how they could be affected by this local artisanal fishery. 


\section{ACKNowledgments}

We thank the fishermen from Caleta Coquimbo, who allowed us to obtain data through sampling of some landed species. To Alejandro Pérez and Philipp Neubauer for advising on statistical analyses.

\section{LITERATURE CITED}

Abarca L, P Gálvez, R Céspedes, A Olguin, H Miranda, L Adarme \& Z Young. 1997. Estudio biológico pesquero de los recursos demersales explotados por la flota artesanal en el litoral de la III y IV Regiones. Informe Final Proyecto FIP 1997-17: 1-243. [on-line] <http://www.fip.cl/FIP/Archivos/ pdf/informes/inffinal\%2097-17.pdf>

Acuña E \& L Cid. 1995. On the ecology of two sympatric flounders of the genus Paralichthys in the bay of Coquimbo, Chile. Netherlands Journal of Sea Research 34: 7-18.

Acuña E, J Moraga \& E Uribe. 1989. La zona de Coquimbo: Un sistema neritico de surgencia de alta productividad. Revista Pacífico Sur (Num. Esp.): 145-157.

Acuña E, JC Villarroel, M Andrade \& A Cortés. 2005. Fauna acompañante en pesquerías de arrastre de crustáceos de Chile: implicancias y desafíos desde la perspectiva de la biodiversidad. In: Figueroa E (ed). Biodiversidad marina: Valoración, usos y perspectivas ¿Hacia dónde va Chile?, pp. 395-425. Editorial Universitaria, Santiago.

Acuña E, JC Villarroel, M Araya, S Hernández, M Andrade \& J Peñailillo. 2007. Estudio biológico-pesquero de los recursos cabinza, machuelo, sierra y blanquillo en la III y IV Regiones. Informes Técnicos FIP, FIP/IT Nº 2006-53: 1-247. [on-line] <http://www.fip.cl/FIP/Archivos/pdf/informes/ inffinal\%202006-53.pdf>

Aedo G, L Cubillos, M Araya, R Meléndez, R Galleguillos \& M Pedraza. 2009. Estudio biológico-pesquero del recurso pejegallo entre la IV y X Regiones. Informes Técnicos FIP, FIP/IT No 2006-18: 1-242.[on-line] <http://www.fip.cl/FIP/ archivos/pdf/informes/inffinal2006-18.pdf>
Amezcua F, J Madrid-Vera \& H Aguirre. 2009. Incidental catches of juvenile fish from an artisanal fishery in a coastal lagoon in the Gulf of California. North American Journal of Fisheries Management 29:245-255.

Lamilla J, E Acuña, M Araya, M Oliva, I Kong, JC Villarroel, S Hernández, F Concha, R Vogler, C Bustamante \& E Mutschke. 2005. Lineamientos básicos para desarrollar el Plan de Acción Nacional de Tiburones. Informes Técnicos FIP. FIP/IT No 2004-18, 2 Vol: 1-214. [on-line] <http:// www.fip.cl/proyectos/2004/2004-18.htm>

Martin LK \& GM Cailliet. 1988a. Aspects of the reproduction of the bat ray, Myliobatis californica Gill, in Central California. Copeia 3: 754-762.

Quinn GP \& MJ Keough. 2002. Experimental design and data analysis for biologists, 537 pp. Cambridge University Press, Cambridge.

SERNAPESCA. 2007. Anuario Estadístico de Pesca. Ministerio de Economía, Fomento y Reconstrucción, Chile. [online]<http://www.sernapesca.cl>

StatSoft. 2004. STATISTICA (data analysis software system), version 7. StatSoft, Inc. [on-line]<www.statsoft.com.>

Stevens JD, R Bonfil, NK Dulvy \& PA Walker. 2000. The effects of fishing on sharks, rays, and chimeras (Chondrichthyan), and the implications for marine ecosystems. ICES Journal of Marine Science 57: 476-494.

Stobutzki I, P Jones \& M Miller. 2003. A comparison of fish bycatch communities between areas open and closed to prawn trawling in an Australian tropical fishery. ICES Journal of Marine Science 60: 951-966.

Thiel M, EC Macaya, E Acuña, WE Arntz, H Bastias, K Brokordt, P Camus, JC Castilla, LR Castro, M Cortés, CP Dumont, R Escribano, M Fernández, JA Gajardo, CF Gaymer, I Gomez, AE González, HE González, PA Haye, JE Illanes, JL Iriarte, DA Lancellotti, G Luna-Jorquera, C Luxoro, PH Manriquez, V Marín, P Muñoz, SA Navarrete, E Perez, E Poulin, J Sellanes, HH Sepulveda, W Stotz, F Tala, A Thomas, CA Vargas, JA Vasquez \& JMA Vega. 2007. The Humbolt Current System of northern and central Chile. Oceanography and Marine Biology: An Annual Review 45: 195-344. 